\title{
A Critical Look at the Teacher Factor in Senior Secondary School Students' Poetic Appreciation Skills Development
}

\author{
Iyabode Omolara Akewo Daniel \\ Department of English, School of Arts and Social Sciences, National Open University of Nigeria, Victoria Island, \\ Lagos, Nigeria
}

\begin{abstract}
The paper examines the teacher factor in the development of poetic appreciation skills among Senior Secondary School (SSS) students. A questionnaire was administered and data collected from two secondary schools in Ibadan, Oyo State, Nigeria. The data is analysed using mean average, frequency count, column chart, and rank scale. The major finding is that the teacher is a significant factor in the development of Senior Secondary School students' poetry appreciation proficiency. Moreover, the effect of book scarcity, which could be severe due to the current economic problems worldwide, could be mitigated through the teacher's creativity. A reconsideration of curriculum choices in terms of recommended poetry texts to reflect familiar African cultural products before the unfamiliar European ones is also advocated.
\end{abstract}

Index Terms-poetry, teacher factor, linguistic incompetence, L2 learners, English language, literature education

\section{INTRODUCTION}

Poetry has been described by many as an artistic creation which is meant to excite the senses. It has also been described as a product of imagination and emotional and imaginative discourse in metrical form, which represents ideas that have special reference to emotional significance (Senanu \& Vincent, 1976; Abrams, 1981). Poetry is an imaginative art and therefore very personal to the poet. Being a product of imagination personal to the poet, it becomes coloured, inspired by the emotions of this person (Akporobaro, 2008; Dasylva \& Jegede, 2005; Egudu, 1977). It is these emotions and ideas private to the poet that we must get at and try to unravel through poetic appreciation.

Poetry is also a discourse. Every discourse makes use of language (Leech, 1969; Toolan, 1998; Chase \& Collier, 1985). This is why some scholars tend to call it language of feeling, which is the perceived notion of poetry by the 18th century Romanticists. William Wordsworth went as far to as to define poetry as the expression of powerful feelings recalled in tranquillity (Wordsworth, 1802). This indicates one quality of poetry that is very obvious and, to many, ominous: intensity (cf. Knapton \& Evans, 1967). Beyond mere emotive display by poetry, some scholars regard it as an organisation of language (Fowler, 1981; Short, 1996; Simpson, 1997). This seems to vindicate the Russian formalists' position that poetry is all sufficient in itself.

The question however is this: Is poetry really self-sufficient? Is the structural form of a poetic piece adequate to give all the meanings derivable from it as a work of art? This remains a source of great controversy for the simple fact that poetry seems to have as its pivot language, because the forms and meanings of literature (poetry) are linguistically generated. It is the tool with which the poet creates their work. Though, it is not a kind of language, it certainly is a use of language. It is a rich exploitation of the reference and relationships inherent in language ((Empson, 1936) in Fowler, 1973).

While linguists, psychologists, and philosophers have pondered on the nature of language for years, the essential consensus is that language is a tool or channel through which information is passed from person to person (cf. Medina, 2005). Language is also seen as an avenue of expressing ideas, and one may dare say, the poet's ideas. As a channel of information (Miller, 1951), language seeks to be meaningful for the receiver of the information to decode the intended message. Poetic language may, therefore, be seen as the language of poetry, or what may also be called poetic diction. If language is thus the expression of ideas, poetic language may be called that which expresses the poet's ideas. It conveys information from the poet to their audience. Obviously, the poet makes use of ordinary language to achieve 'effect', which often arose from a rich exploitation of the references and relationships inherent in language.

It is this exploitation of the references and relationships in language to give a seeming deviatory and more than ordinary moulding of language that gives the aesthetic challenge to the sensibility. It makes language of poetry sophisticated and special. According to Lewin et al (1965) in Encyclopaedia of Poetry and Poetics, if poetic language is characterised by deviation from the grammatical rules, it must of necessity fall outside the scope of the study of ordinary utterances by linguists. It therefore appears that poetry is written from the grammatical rules that are different from the grammatical rules governing ordinary language. This has been described as poetic license. But the question is: 
against what norm do we compare poetic language (cf. James, 1998)? For there to be a deviation, there should be a norm, whether deliberate or non-deliberate.

All literary works are verbal constructs. They are created from language, which is the tool that the creator uses to actualise their imaginary micro world. The language of the society thus becomes the norm from which the poet deviates. It is a known fact that one of the accepted characteristics of language is convention. This convention of language in society is thus seen as the norm of language use in that society, which a deviation could be safely measured against. Nevertheless, one needs to mention that the concept of deviation from the norm as a literary style remains a very controversial issue. Jan Mukarovsky calls deviation foregrounding, which involves making some distinct linguistic features prominent in a work (Freeman, 1970). But to Halliday (1971), foregrounding is also an attainment of a norm by the writer. Leech and Short (1981), however, suggest that norm should be determined in relative terms, that is, in comparison to the author's other works or to other works within the genre.

Having said this much, the concern in this paper is: how do all these affect the learning of poetry in Senior Secondary Schools (SSSs) in Nigeria? The very fact that the channel through which poetry in Nigerian schools is learnt is the English language makes a pause necessary here. Is it poetry itself that is a problem or the language that is being used to teach it? Is it that the students are not highly motivated to learn it or are they? Are the teachers and their methods of teaching poetry the problem?

The position of the English language in Nigeria cannot be overstated. It is very important in the instruction of the Nigerian students. It is actually the language of instruction in the secondary schools (National Policy on Education, 2004). It is thus rather difficult to avoid the use of English in the secondary schools. Moreover, as the subject in which poetry is taught in Nigerian Senior Secondary Schools is tagged Literature-in-English, English as medium of instruction is unavoidable. As poetry has been described as an organisation of language, it is clear that poetry taught to Nigerian secondary school students is the organisation of the English language.

Learning is a change in the behaviour of the learner (Tella, Ajayi \& Olowoye, 2004). This change in behaviour must be positive as judged by the educator. It is considered progressive in terms of the value placed on it by this educator. The learner of poetry thus needs to be able to decipher what is put inside of the poetry they are analysing to be adjudged as having learnt that poetry. They see what is of aesthetic value and the style used by the poet to achieve this. They have some desire or interest to appreciate what is beautiful in the work. All these combine to make them want to unravel the 'defamiliarised language'. The process of defamiliarisation must become familiar (Wales, 1989).

However, this depends on how much they can relate to what they are learning (cf. Bala, 2011). Students get motivated to learn if they consider the material to be learned meaningful to them (Encyclopaedia of Education, 1977). The concept of meaningfulness refers to the extent to which the material relates to the things that the students are familiar with. This is however one of the identified problems of poetry learning in Nigeria. Haynes (1979) states that "in poetry teaching, we tend to confront students with 'advanced' work at the outset" (p. 207). He adds that students with little or no knowledge of poetry before get confronted with sophisticated texts of Wordsworth, Keats, Byron, etc. "which tax even the native speakers." When the native speakers of the English language have problem with English poems, how much more the learner reading them through a second language?

This method may not help the Nigerian secondary school students to perceive the message content in poems but merely get frustrated at what they cannot perceive. It may lead to fixed attitudes or even prejudice against poetry. The non-interest of many Nigerian secondary school students in poetry evidently supports this viewpoint (cf. Bala, 2011). This is without prejudice to the assertion by Knapton and Evans (1967) that even American students with English as their first language also tend to stop reading poetry after completing their English class program. They lose sight of the valuable message that may be contained in poems. The idea of noise as stipulated in Miller's (1951) model of communication consequently becomes a reality. He defines noise as any interference factor in the process of communication. This noise may take the form of lack of prior understanding of the information. Error in communication thus results.

But this may not be the only cause of 'noise' to the appreciative ability of the Nigerian learner. Another kind of interference is what may be called that which results from lack of competence. This competence is essentially the linguistic one as professed by Ferdinand de Saussure in his theory of 'langue' and 'parole' (Chomsky, 1965). This focus on competence versus performance has generated a lot of debate among linguists, especially between generativists and functionalists (cf. Adegoju, 2005; Alo, 2005; Chomsky, 1965; Daniel, 2008; Dik, 1986; Halliday, 1985; Gray, 1978; Hudson, 1980; Newmeyer, 2001; Ogunsiji, 2004; Olaoye, 2007). However, this writer's view on the matter remain s that competence and performance are actually complementary elements. Competence is essentially about ability, a mastery of a particular task. Inability to perform this task will make the person ineffective. A student that lacks understanding of the language used to write a poem will definitely find it an uphill task to appreciate such a poem. Competence in the language in which the poetry to be appreciated is written thus becomes crucial to unravelling the message of the poet. How to achieve this competence is consequently crucial to the task of appreciating poems by the secondary school students.

English is a second language in Nigeria. This fact makes it one that can only be learnt to different degrees of competence under various conditions. Using English as L2 is an activity superimposed on the prior mastery of one's first language and is a different process intellectually. The degree of competence in the English language is a reflection 
on how well students can appreciate poetry. If students find it difficult to understand a simple sentence in its denotative form, one can only imagine what will happen when this sentence is inverted or manipulated to seem like something else. This is because tolerance of deviation is very high in poetry (Wales, 1989). If this is so, students still grappling with the denotative use of the English language would likely encounter a greater problem in its connotation; especially, as this connotation is concentrated, intense and emotive. The meaning in the figurative language is also essentially culturebound. It is interpreted in terms of or in reference to a culture. All these will therefore have implication for the aptitude of the students to interpret poems.

Vincent (1979) alleges that teachers of poetry in the Nigerian secondary schools were badly taught on how to teach poetry. Eriche (2012) asserts that the quality of the curriculum content of the teacher education naturally has implication for the quality of instruction given to students. Looking at the identified problems that students of literature may encounter, one fears that the capacity of such teachers to get across the necessary information contained in the poetic diction used by authors may become problematic. This is even more critical in the face of the observation by Haynes (1979) that educators tend to confront students of literature in Nigeria with poems that strain even the native speakers of English. Linking this to the problems of linguistic incompetence that confronts many of these students that have the English language as their L2 in Nigeria, one considers it pertinent that a critical look needs to be taken at the teacher factor in developing the appreciative skills of secondary school students in poetry. Literature remains an important means of preserving the culture of any people. So also is the ability to appreciate literary works a very important means of attaining levels of education and culture that only high and critical thinking can produce. The teacher factor in all these thus becomes crucial as it is the factor that coordinates the process of achieving true and positive change in behaviour by the learner.

Objective of the Study

This paper set out to investigate the effect of the teacher factor on the ability of secondary school students to appreciate poetry.

\section{Research Design}

This study is a survey of the general attitudes of students in the Senior Secondary School literature class to the appreciation of poetry, with particular reference to the role of the teacher in the process of developing the students' poetic appreciation skills.

\section{Research Question}

To what extent does the teacher affect the SSS students' interest and skill in appreciating poetry?

\section{METHODOLOGY}

\section{Sample Population}

A purposive sampling technique is used to obtain the sample population of 105 from two schools in Ibadan. The students used as the study sample are those offering literature-in-English in the SSS classes in the schools used. It is important to note that Ibadan is a metropolitan city, actually, the third largest in Africa. It is thus expected that at different levels, the population sample is representative in terms of background and exposure to poetry. Moreover, the population is made up of a mixture of boys and girls in the Senior Secondary School level, that is, SS1, SS2, and SS3 classes thus showing a structural make up of the population in terms of levels of formal exposure to poetry. International School (ISI), University of Ibadan, Ibadan and Orogun Grammar School (OGS), Orogun, Ibadan are the two schools used. These two schools have diverse economic and social orientations. One is what you will call a school for privileged children (ISI), while the other is for the 'boys downtown' (no gender prejudice intended). The total population from these schools is 105 . This makes up the literature students who were available at the time of administering the questionnaire. Specifically, 40 students made up of 30 females and 10 males were given the questionnaires in ISI and 65 made up of 44 females and 21 males turned up for the class during which the questionnaires were administered in OGS. The impression given by the summary in the table below is that there are more females in the literature class.

TABLE 1:

POPULATION SAMPLE

\begin{tabular}{|l|l|l|}
\hline \multicolumn{3}{|c}{ POPULATION SAMPLE } \\
\hline Schools & Sex & No. \\
\hline International School, Ibadan & F & 30 \\
& M & 10 \\
\hline Orogun Grammar School, Ibadan & F & 44 \\
& M & 21 \\
\hline Total & 105 \\
\hline
\end{tabular}

Does this trend have any implication for this study? This is not the issue of focus in this study.

\section{Instrument of Data Collection}

A questionnaire is used to collect data for the study. The instrument is tagged 'Questionnaire on the Problem of Poetic Appreciation among SSS Students' (QPPA). It is constructed along two main parts. These are in line with the foci of the information sought in the study while the population it was administered to could be considered representative within the Nigerian socio-educational milieu. The instrument is thus considered valid and reliable. The 
first part has 14 questions, which are in the alternative choice form. These seeming questions are statements of expression of opinion on the students' attitude to poetry, poets, teachers, and possible psychological and sociological factors that may interfere with or affect their learning of poetry. These choices are expected to help narrow down their responses to manageable proportions. They are essentially meant to elicit the motivational and attitudinal postures of the students to poetry. The second part of the questionnaire seeks to unravel the linguistic difficulties they encounter in the course of studying poetry. These likely linguistic difficulties are vocabulary problems, expressions, figures of speech, grammar, and interpretation. They are expected to reorganise these items in their perceived order of difficulty. The data collected from the instrument is then analysed using descriptive statistics. The first section is analysed using the average mean as well as the frequency of occurrence. Column graph is then used to present the pictorial representation of the students' attitudes. Ranking scale is applied to the linguistic difficulties. These different sections are analysed based on the focus of information sought. They are then presented in three different tables and a column chart to demonstrate this.

Procedure

Questionnaires were administered in the two schools on two different days. The literature teachers' in the two schools were very helpful in organising the students for the successful administration of the questionnaires. The questionnaires were given out to the students in both schools on each day with the express instruction that they should take their time in giving their opinions on each of the items. They were discouraged from doing group work but rather encouraged to take options that strictly reflect their individual opinions on the items in the questionnaires. Moreover, they were encouraged to seek clarification on any item that is not clear to them from the researcher. Even though some of them attempted to do group discussions on the questionnaire, this was discouraged and they were once again reminded to direct their questions to the field personnel. The questionnaires were retrieved after some time on their filling in their responses.

\section{Data Analysis}

A corpus of data was collected from the responses given by the students in the questionnaires. The data are first studied in terms of the sex and schools of the population sample as shown in Table 1 above. Some of the statements in the questionnaires are scored with units of 4, 3, 2, 1 assigned to the alternative choices. The average means of these scores are then found. Frequency count is also done to analyse the data. These are ranked according to their frequency of occurrence and presented in tabular and graphic forms. The levels of linguistic difficulties are also ranked to reveal what the students consider their most de-motivating linguistic difficulty.

\section{RESULT}

TABLE 2:

STUDENTS' MOTIVATION FOR POETRY READING

\begin{tabular}{|l|l|l|}
\hline Item & No. & Mean Average \\
\hline How many students like poetry & 1 & 3.5 \\
\hline Why do they read it & 3 & 3.5 \\
\hline When do they read it & 4 & 3.4 \\
\hline How much do they admire poets & 5 & 3.4 \\
\hline How easy do they consider it & 11 & 3.1 \\
\hline How often do they read it & 13 & 2.8 \\
\hline Maximum & 4.0 \\
\hline
\end{tabular}

From Table 2, it appears that the learners' motivation for reading poetry is very high. Item 1 that seeks to find out the number of students that like poetry does well in their responses. It receives a mean average of 3.5. This shows that it remains only 0.5 for the mean to reach a perfect expression of liking for poetry. However, the not so good showing of Item 4 on their frequency of reading poetry raises doubts about how well they understand Item 1 . Nonetheless, the general performance of their desire to read poetry appears passably good, indicating a high motivation for reading poetry.

TABLE 3:

ATTITUDES OF STUDENTS TO POETRY AND THE TEACHER

\begin{tabular}{|l|l|l|}
\hline Items & No. & Frequency \\
\hline Those that consider poetry easy rather than difficult & 12 & 84 \\
\hline Those finding the teacher positive though not exceptional & 9 & 81 \\
\hline Those that compare poetry to tales & 6 & 78 \\
\hline Those that can decipher the real nature of poetry & 8 & 48 \\
\hline Those that read it to learn & 10 & 42 \\
\hline Those that like rhythm in poetry & 2 & 42 \\
\hline The most militating problem of book scarcity & 14 & 44.1 \\
\hline
\end{tabular}

The chart below presents a graphic representation of the frequency count of students' attitudinal postures to poetry reading and the teacher. 


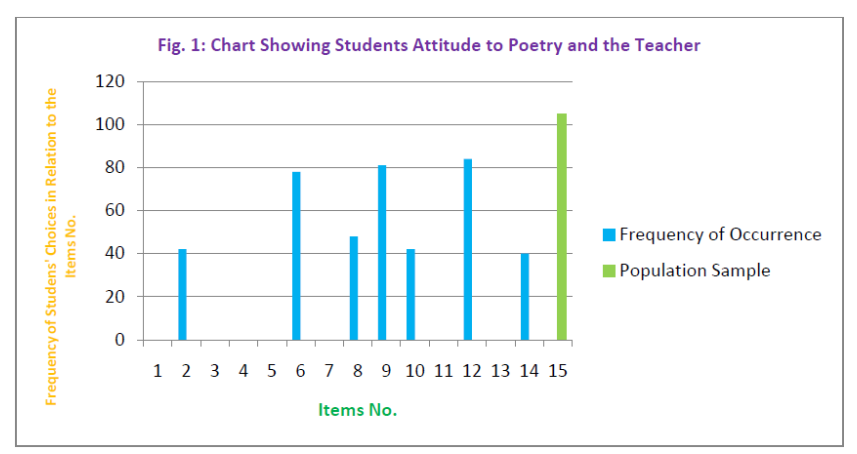

Table 3 and Figure 1 reveal the sort of attitude the students have towards poetry reading. From the table and the chart, it is observed that they apparently have a generally positive attitude towards the reading of poetry. The fact that 84 $(80 \%)$ of the students think that poetry is easy rather than difficult gives this impression of a positive attitude to poetry. This marks the highest number on the students attitude frequency scale. The specifics of what they consider positive about poetry are its rhythmic nature (40\%) even though it seems to them more like telling of tales (74.3\%). Musicality combined with content is thus a factor in the students' attraction to poetry. This shows that they can perceive the content and form of poetry on its substantive basis. This is significant because it shows that a good number of them are of the opinion that it has information to give or a story to tell, which, in their view, it seems to tell in an enjoyable manner. Poetry to them is thus not mere form; it has substance. It can thus be deduced that poetry is not a mere abstraction to them but something they can relate to, just like story-telling.

This appears to help them to appreciate the real nature of poetry. Even though not many of them did, a mere 48 $(45.7 \%)$ of them, this still makes up the majority for the question. They therefore see poetry as accessible rather than being too difficult and unrealistic in Item 6 . This may also be attributed to the perception of the teacher's contribution. To their mind, the teacher makes poetry something interesting to learn about, so they want to learn about it; without much prodding, that is. $81(77.1 \%)$ of them hold this view as shown in their responses to Item 12. It thus appears that the teacher factor is relevant as a contributory factor to kindling their interest in poetry. Nevertheless, many of the students consider book scarcity as the biggest militating factor against poetry reading as seen in their responses in Item 14. This sociological factor is seen as central to the problem facing their ability to develop a good poetic appreciation skill. It thus appears from Table 3 and Figure 1 that students generally view poetry reading in a very positive light, at least not as negatively as one feared as expressed above.

TABLE 4:

Perceived Linguistic Difficulties CONFRONTING STUdENTs IN POETIC APPRECIATION IN RANKING ORDER

\begin{tabular}{|l|l|l|l|l|l|l|l|}
\hline \multicolumn{2}{|l|}{ Itemised Linguistic Difficulties } & \multicolumn{2}{|l|}{ Scoring of Linguistic Difficulties } & \multicolumn{2}{l|}{ Ranking Order of Difficulties } \\
\cline { 3 - 9 } \multicolumn{2}{|l|}{} & Difficulties & Scores & Rank & Difficulties \\
\hline A & Vocabulary Problems & $1 \ldots \ldots \ldots \ldots$ & A & Vocabulary Problems & 2 & 1 & Interpretation \\
\hline B & Expression & $2 \ldots \ldots \ldots \ldots$ & B & Expression & 4 & 2 & Expression \\
\hline C & Figures of Speech & $3 \ldots \ldots \ldots \ldots$ & C & Figures of Speech & 3 & 3 & Figures of Speech \\
\hline D & Grammar & $4 \ldots \ldots \ldots \ldots$ & D & Grammar & 1 & 4 & Vocabulary Problems \\
\hline E & Interpretation & $5 \ldots \ldots \ldots \ldots$ & E & Interpretation & 5 & 5 & Grammar \\
\hline
\end{tabular}

The second section of the questionnaire asks about the linguistic difficulties the students encounter in poetic appreciation. In reordering these linguistic difficulties on a scale of 1-5 in terms of magnitude of difficulty, it becomes obvious in Table 4 that grammar is considered the least difficult and interpretation the greatest. The first column gives the list of linguistic difficulties as presented in the questionnaire while the second column presents the average scores given to each difficulty by the students. The third column presents the ranking order of the linguistic difficulties. From Table 4, interpretation ranks highest in terms of difficulty magnitude. This is followed by expression and figures of speech, which were used to beautify the poems. One could surmise that these linguistic adornments make the words lose their original meaning or just deepen such meaning. But the grammar of the language may prove least troublesome because the student has become familiar with the grammar of English, having been so frequently exposed to it since the primary education level.

\section{DiSCUSSION OF FINDINGS AND RECOMMENDATIONS}

Two important issues stare us in the face from the analysis done so far. The first one is the issue of linguistic incompetence in the L2 by many of the students, which reveals itself in the fact that they find the language of poetry top heavy, that is, inaccessible. As noted above, poetic diction tends to be a result of the poet's attempt to make even familiar English language, which poses enough challenge to the Nigerian secondary school students, unfamiliar through syntactic and vocabulary idiosyncrasies of the poet. A point made above that is also crucial to the linguistic problem is the fact that many of the poems teachers choose for their literature classes tend to be unfamiliar to the students' cultural background (cf. Young, 2010). As noted above, an unfamiliar material in the educational process will most likely turn 
off the learning antenna of the student. This makes the teacher factor very crucial to students' poetry learning tasks, especially in terms of the use of their discretion in the choice of poems students study. This is not to lose sight of the part played by those who recommend the texts to be used by the teacher in all these as well as the availability of such texts as the identified problem of book scarcity shows in Table 3. In the face of the global economic meltdown that is prevalent now, a teacher's discretion in choosing available books in the country would be the wisest option. But as noted below, curriculum planners have a lot to do with this issue of text availability. For the ODL practice, the point is that the facilitator needs to be innovative in the poetry class. It goes without saying that the instructional designer is central in making such available recommended texts the focus of the material design of literature-focused English course material.

The next issue to tackle is the teacher factor. How does the teacher factor play out in the process of poetry learning by students in the secondary school level? The analysis above in Table 3 reveals a positive rating for the teacher; it is the option with the second highest frequency of occurrence. However, looking more critically at the students' responses reveals that even though these 81 respondents look at the teacher as an important factor to their developing their poetic appreciation skill, they do not consider the teacher as adding a great deal of value to their interest in poetic appreciation (Item 12). Why this may seem so is that they think the teacher is not doing enough to help them develop more than their basic skill in poetic appreciation. This agrees with Haynes (1979) observation on this same problem in poetry teaching. Even though the teacher makes poetry learning interesting, they do not consider such lessons lively enough to sustain their interest. The positive rating of the teacher by such a high number of the respondents shows hope, though, when one compares this result with Vincent $(1979$, p. 219) assertion that Nigerian teachers "were badly educated on how to teach poetry generally," one may therefore look at the students seeing poetry as something easy to learn as attributable to the teachers' efforts. One may, however, wonder if learning about poetry is the main reason why poems are written. Nonetheless, in a literature class, poetry is meant to be learnt and taught (Knapton \& Evans, 1967). The guide for such young minds in the secondary education level is thus the teacher.

Evidently, there is no way that the attitude of the teacher towards the subject they are teaching or their approach will not affect it (Eriche, 2012). In consequence, a negative or not overtly positive attitude or approach is likely to elicit a negative response from the students. Young (2010) actually fears that teacher's bias in the classroom is an important mitigating factor to classroom effectiveness of pedagogical practices. The respondents to the questionnaire do not believe that the teacher is negative or uncommitted. They only perceive the teacher's efforts as not being (good) enough. This may not be unconnected with what Vincent (1979) calls the teachers being 'badly educated'. If the teacher does not have a good mastery of the subject they are to teach, it spells doom for the future of the subject in question (cf. Eriche, 2012). This does not really encourage the learner.

In the first place, many teachers lack the historical background in the teaching of their cultural heritage to draw from in their poetry teaching tasks. Secondly, the curriculum of their studies as student teachers does not allow them to really specialise in either language or literature. This assertion is based on the system as it exists in the Department of Teacher Education, University of Ibadan, School of Education, National Open University of Nigeria INOUN), and the college of education system as it exists in the Federal College of Education, Okene (which mostly derive their curricula from the supervising commissions' benchmark documents). Moreover, due to a lack of total mastery of the subject content, the teacher is unable to adequately impart the substance of learning to the students. What happens is that the teacher rather glides over the subject content and leaves the rest, which Haynes (1979) calls superficial teaching. To whom does the teacher leave the rest of what the students are to learn? one may ask. The learner is thus left unfulfilled and frustrated: having not learnt much about the real skills required for independent poetic appreciation.

The suggestion is thus that the teacher should be given a good and adequate education. This should be intensive, at the outset, and continual, subsequently. A teacher should constantly learn and update their knowledge on what is happening in their field of specialisation. Nigeria English Studies Association (NESA) is a good forum for doing this, through attending its annual conferences; the teacher is also someone to be educated constantly, not minding the economic implication. Eriche (2012) agrees with our postulation here as he also insists that quality (recurrent) training is what gives birth to quality delivery. One must commend the National Open University for the constant workshops that it exposes its staff to on the practice of the Open and Distance Learning. Probably, the new nature of the ODL practice in Nigeria and the fact that many of these staff members are usually drawn for the conventional system accounts for this dogged commitment to training and retraining of the NOUN staff, time will tell. The point is that a teacher should be constantly exposed to new practices in their field.

It should be taken into account that the organisation of the Nigerian educational system encourages specialisation for the maximisation of skill utilisation. A curriculum for teachers of English should therefore be drawn up which produces either language specialists or literature specialists for the secondary schools. What the teachers know very well they are likely to deliver even better. The National Commission for Colleges of Education (NCCE) double major curriculum in English should be the focus in colleges of education, while the curriculum departments in the universities should let student teachers specialise in either language or literature the same way BA students do in the departments of English of conventional universities. This same generalist tendency had been seriously questioned by Daniel (2010) in critiquing the present structure of the National Open University of Nigeria BA English programme. Specialisation is a crucial means of raising effective teachers in the classroom. 
The teacher in the class should make sure that the students are involved at every stage of the lesson. The teacher may ask the students to dramatise poems in an informal fashion. This brings the message home to them quickly. This writer has used this method and found it very effective in poetry teaching. The teacher could also encourage the students to write their own poems. The teacher helps them to look at the poems in order to lead, guide, and correct them where necessary. That supposedly dull child, because of poor performance in mathematics, may actually be a potentially great poet. Releasing the students' creative energy may even make the teacher's work much easier in that when they see the tricks required to manipulate language for effect in creating poems, they will become better at unravelling the poetic creations of others. This is beside the fact that this positive channelling of youthful energy could prevent some of them from easily falling prey to the deceit of terrorist gangs.

The teacher can also help by maintaining a sort of invisible or floating library in their class in which different people bring different books on poetry. These are then exchanged in the class. The students can discuss what has been read in the class while the teacher moderates. They should be encouraged to always do a critique of whatever they read, even orally. This sharpens their thinking/critical faculty.

A very crucial problem that could hinder succeeding in all these is the issue of curriculum and the works students are required to read. John Haynes (1979, p. 207) makes an important point when he connects all that has been said to the educational curriculum:

A problem in poetry teaching at the introductory level with second language students is that...we do not normally begin... with simple isolated problem, proceeding to increase difficulty in stages; in poetry teaching, we tend to confront students with 'advanced' work at the outset...sophisticated texts which tax even native speakers.

If this should be so, one wonders why this approach is used and why it is still expected that students should understand and master poetry.

The fact that students are confronted with 'advanced' work at the outset rather than starting from the simple isolated problems shows that the psychological principle of from known to the unknown, simple to complex and so forth has been turned upside-down [see a full outline of this principle expressed as Maxims of Teaching in Eya (2012, p. 25)]. Curriculum planners should be aware that this sort of approach usually leaves the poor student floundering at the sea of the unfamiliar; the teacher becomes a pilot without a real compass and can therefore not safely lead students to destination. If the learning of poetry in English sometimes confounds the native speaker, what more can be expected from the second language learner.

The teacher and curriculum planners thus have the task of making literature education relevant to the students. They should give them such materials which they can associate with as the background knowledge before all other things should follow (Tella, Ajayi \& Olowoye, 2004). It should not be the other way round. Students should learn about Africa before going outside. They should first be introduced to poets and poetry books that are available in Africa before searching for the elusive foreign texts. Should not Nigerian students learn about the raining season in Africa as it exists in J. P. Clark's "Night Rain" before going to learn about the distant freezing snow? Is it not better to learn about the free flowing African blank verses before going into the staccato couplets and metres of the Europeans? The submission is YES. The curriculum planners need to answer these questions. But more importantly, the discretion of the wise and effective teacher will always provide the way out.

\section{The Open and Distance Learning Connection}

The Bachelors degree of education in the English programme should enable the trainee teacher to specialise. However, as it is only with the servicing department that this could be done, a programme that would allow this is necessary in the BA English programme to enable the BA Ed programme to have sources to feed its students. It is thus gladdening to note that a serious overhaul of the NOUN BA English programme has been done to make this possible with the increased literature content (You may see the revised DPP and the NOUN forthcoming Catalogue that contain this review). All that remains is that the education component restructures its own programme to make this possibility happen.

In addition, the place of the Open and Distance Learning (ODL) practice in the issues raised above is in terms of the material design. Usually, the teacher factor has to do with the preparation of course materials in the ODL practice. It is thus essential that the teacher curriculum be such that can allow the trainee teacher to be innovative (cf. Daniel, 2012). In this wise, the materials designed for the teacher of the subjects in the literature-in-English component of the English programme in any ODL focused teacher training institution should be such that can enable the teacher become innovative. But at a closer range, the designer of the material needs to be proactive in terms of the content of such course materials. As one has done in a practical class of literature methodology in the delivery of poetry teaching techniques, it could be such that the effective material designer for the literature class should be able to bring into play so many factors to make the material content easily accessible to the ODL students. As asserted by Daniel (2012a), technology should become an important ally of that teacher that intends to succeed in the modern class.

The class of the ODL practitioner is usually the instructional material prepared for the student, whether trainee teacher or just the plain BA students of the English programme. Attempts at not only making the local content of the material very high but also making sure that it is designed in such a manner that an interactive media like the video can be a part of the content to make the accessibility of the material of a much higher possibility. NOUN is presently using 
its radio, FM105.9, as a means of doing some of these. Television delivery will definitely raise the stakes higher for the University in terms of impact and effectiveness.

At the present, the materials designed for the literature classes in the English programme of the National Open University of Nigeria are very much compliant with the local content requirement. This suggests that the material designers of NOUN have usually been made to play critical role in making literature an accessible and relevant content to the learning process of the NOUN student. Even though this study is actually focused on the secondary education level, the pedagogy of accessibility of learning content remains essentially the same. For the ODL practitioner then, the quality of the material design is the crucial issue. If the instructor, in this case the instructional designer, hopes to make any impact in the life of the students to use the material designed for self-study, it must be made such that the student's study time is exciting as well as adding to cultural pride and enrichment due to the teacher's (material designer's) efforts.

The teacher thus remains an essential pivot in the success of the educational process. Nevertheless, the end result of such a pivotal role should be the reproduction of the self in the kind of teachers that can go into the field, whether in the conventional or ODL mode, and be able to make qualitative impact in the students learning process in any class of study for that matter.

\section{CONCLUSION}

This paper has discussed the special nature of poetry, identifying some important factors that shape secondary school students' ability to appreciate it. It identified the teacher as an important factor in the whole process of developing students' skill in poetry appreciation. The capability of the teacher to help students develop a proper competence in the English language and confidence in poetry appreciation is considered a major requirement for the effective teacher of literature. It is thus concluded that, as those entrusted with the task of developing the minds of young Nigerians, the teachers have to look inward to improve their delivery. Giving quality teacher education and encouraging a frequent inservice training is considered crucial to re-invigorating literature education in Nigeria, with particular reference to poetic appreciation development skill of Senior Secondary School students. Despite the global economic meltdown, the creative teacher will produce students of the future through creative teaching. But the government cannot afford to ignore the recommendations proffered above if Nigeria will go beyond the seeming perpetual economic meltdown that has plagued it since the mid-80s.

\section{ApPendix Questionnaire on the Problems of Poetic APPRECIATION AMONG SSS Students}

AGE:

SEX:

\section{CLASS:}

SCHOOL:

All information will be treated with utmost CONFIDENCE.

INSTRUCTION: Please, circle any answer you choose from questions 1-14.

\section{I like poems.}
a. very much
b. fairly well
c. only a bit
d. not at all

2. I like poems because of its
a. stanzas
b. metric lines
c. rhythm
d. rhyme scheme

3. Poems are
a. very easy
b. fairly easy
c. fairly difficult
d. very difficult

4. I read poems.
a. always
b. often
c. once in a while
d. not at all
5. I read poems...
a. for enjoyment
b. just for class work
c. just to pass exams 
d. only for assignments

6. I found poetry usually
a. very deep
b. very technical
c. very involved
d. very easily understandable

7. Poetry captures
a. the essence of the world
b. the ugliness of the world
c. nothing that I can see
d. the beauty and essence of the world

8. In poems,
a. a little is being said in few words
b. a lots is being said in many words
c. a lot is being said in very few words
$\mathrm{d}$. a little is being said in many words

9. To me, poetry is like
a. Story-telling
b. Music
c. Mathematics
d. Nothing

10. I read poems
a. for their worth
b. for their beauty
c. if I don't find anything else to read
d. to learn about them

11. I read poems
a. only when we have poetry lesson
b. only with the help of the teacher
c. on my own at school
d. on my own at home

12. My literature teacher makes poetry
a. interesting
b. boring
c. uninteresting
d. very lively

13. I
a. admire
b. am indifferent to
c. don't admire
d. don't really have any opinion about

for us

14. I don't read poetry as often as I will like to because

a. my parents are illiterates so never introduced me to it

b. my parents are educated but don't read such things like poems

c. there are not many published books on poetry

d. my teacher doesn't give us the idea of the poetry book to read

15. Here is a list of difficulties one can find in poetry. List the items in order of importance to you. Start with the most important difficulty.
A. Vocabulary Problems
B. Expressions
C. Figures of Speech
D. Grammar
E. Interpretation

1. 
Nonetheless, any perceived shortcomings in the paper remain absolutely mine.

\section{REFERENCES}

[1] Abrams, M. (1981). A Glossary of Literary Terms. New York: Holt, Renehart and Winston.

[2] Adegoju, A. (2005). A Stylistic Study of the Speeches of some Key Actors of the 'June 12' Crisis in Nigeria (1993-1998). PhD Thesis, Department of English, University of Ibadan, Ibadan.

[3] Alo, M. A. (2005). Revisiting Issues in English Use and Usage in Nigeria: Implications for ESL Classroom. Journal of the Nigerian English Studies Association, 11:1, 114-130.

[4] Akporobaro, F. B. O. (2008). Poetry. Lagos: Princeton Publishing Co.

[5] Bala, I. (2011). Teaching Poetry and the Question of Difficulty: An Overview. Journal of Nigeria English Studies Association, $14: 2,82-93$.

[6] Chase, M. \& Collier, P. (1985). An Introduction to Literature. New York: Harcourt, Brace and Jovanovich.

[7] Chomsky, N. (1965). Aspects of the Theory of Syntax. Massachussetts: MIT Press.

[8] Daniel, I. O. (2008). The Linguistic and Pictorial Representation of Nigerian Women's Assertiveness in Selected Nigerian Newspapers. PhD Thesis, Department of English, University of Ibadan, Ibadan.

[9] Daniel, I. O. (2010). Displacing Gender Inequality through ODL: The National Open University of Nigeria English Programme as a Potential Tool. A paper presented at the Sixth Pan-Commonwealth Forum (PCF6), Kochi, India, 24-28 November.

[10] Daniel, I. O. A. (2012). Comparison of Continuous Assessment and Examination Scores in an English Speech Work Class. International Journal of Applied Linguistics and English Literature, 1:6, 92-98.

[11] Daniel, I. O. (2012a). Evolutionary Trends in English Language Material Design. Research Journal in Organizational Psychology and Educational Studies, 1:1, 13-18.

[12] Dasylva, A. \& Jegede O. (2005). Studies in Poetry. Ibadan: Stirling-Horden Publishers (Nig.) Ltd.

[13] Dik, S. C. (1986). Functional Explanation in Linguistics. Belgian Journal of Linguistics, 1 , 11-52.

[14] Egudu, R. (1977). The Study of Poetry. London: Oxford University Press.

[15] Encyclopaedia of Education. (1977). New York: The Macmillian Compary and Free Press.

[16] Encyclopaedia of Poetry and Poetics. (1965). Princeton, New Jersey: Princeton University.

[17] Eriche, J. (2012). Quality Teacher Training Content of the Curricula for the Trainee Teacher, FRCN News Commentary. Federal Radio Corporation of Nigeria National News, 24 April.

[18] Eya, P. (2012). Marriage of Curriculum and Instruction: Reasons, Results, and Witnesses. National Open University of Nigeria 3rd Inauguaral Lecture Series, 23 April. Lagos: Directorate Instructional Resources \& Development, NOUN

[19] Federal Republic of Nigeria. (2004). National Policy on Education (4th ed). Lagos. NERDC Press.

[20] Fowler, R. (1973). A Dictionary of Modern Critical Terms. London: Routledge and Kegan Paul Ltd.

[21] Fowler, R. (1981). Literature as Social Discourse: The Practice of Linguistic Criticism. New York: Routledge.

[22] Freeman, D. C. (1970). Linguistic Approaches to Literature. In D. C. Freeman, Linguistics and Literary Style. Massachusetts: Hold Reinhart.

[23] Gray, B. (1978). Is There a Case against TG? Linguistics, 205, 5-14.

[24] Halliday, M. A. K. (1985). An Introduction to Functional Grammar. London: Edward Arnold.

[25] Halliday, M. A. K. (1971). Linguistic Function and Literary Style - An Inquiry into the Language of William Golding's The Inheritors. In S. Chatman, Literary Style - A Symposium (pp. 330-368). London: Oxford University Press.

[26] Haynes, J. (1979). Poetry Teaching as Language Teaching. In E. Ubahakwe, The Teaching of English Studies: Readings for Colleges and Universities (pp. 207-216). Ibadan: Ibadan University Press.

[27] Hudson, R. A. (1980). Sociolinguistics. Cambridge: Cambridge University Press.

[28] Knapson, J. \& Evans, B. (1967). Teaching a Literature-Centered English Program. New York: Random House.

[29] Leech, G. (1969). A Linguistic Guide to English Poetry. London: Longman.

[30] Leech, G. \& Short, M. (1981). Style in Fiction. London: Longman.

[31] Medina, J. (2005). Language: Key Concepts in Philosophy. London and New York: Continuum.

[32] Miller, G. A. (1951). Language and Communication. New York: McGraw-Hill.

[33] Newmeyer, F. J. (2001). The Prague School and North America Functionalist Approaches to Syntax. Journal of Linguistics, 37 , 101-126.

[34] Ogunsiji, A. (2004). Developing the Basic Language Skills for Communicative Competence in Learners of English as a Second Language in Nigeria. Ibadan Journal of English Studies, 1, 19-34.

[35] Olaoye, A. A. (2007). Introduction to Sociolinguistics. Abuja: Ogunleye Publishing and Printing Press.

[36] Senanu, K. \& Vincent, T. (1976). A Selection of African Poetry. London: Longman.

[37] Short, M. (1996). Exploring the Language of Poems, Plays and Prose. London: Longman.

[38] Simpson, P. (1997). The Language of Literature. New York: Routledge.

[39] Tella, O., Ajayi, T. \& Olowoye, B. (2004). Becoming a Teacher: An Introduction to Teacher Education (2nd edn.). Abeokuta: Sodipo Press Ltd.

[40] Toolan, M. (1998). Language in Literature: An Introduction to Stylistics. London: Hodder Arnold.

[41] Vincent, T. (1979). The Teaching of Modern African Poetry in Schools and Colleges. In E. Ubahakwe, The Teaching of English Studies: Readings for Colleges and Universities (pp. 217-233). Ibadan: Ibadan University Press.

[42] Wales, K. (1989). A Dictionary of Stylistics. London: Longman.

[43] Wordsworth, W. (1802). Wordsworth's Preface of 1800, with a Collation of the Enlarged Preface of 1802. In W. J. B. Owens (1969) Wordsworth's and Coleridge Lyrical Ballads 1798 (2nd edn.). Oxford: Oxford University Press.

[44] Young, E. (2010). Challenges to Conceptualising and Actualising Culturally Relevant Pedagogy: How Viable is the Theory in Classroom Practice. Journal of Teacher Education, May/June, 61, 248-260. 


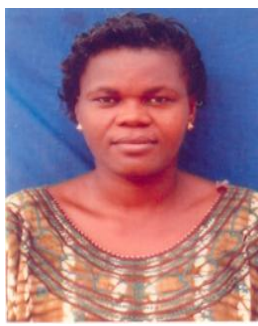

Iyabode Omolara Akewo Daniel, PhD is a scholar of English linguistics. She has published in reputable national and international journals. Her book, Introductory Phonetics and Phonology of English (2011), was published by the Cambridge Scholars Publishing in the United Kingdom.

Her research interests include sociolinguistics, syntax, phonetics and phonology, gender and media studies, and psycholinguistics. She has published in all of these areas.

Dr. Daniel is currently the Head of the English Unit of the National Open University of Nigeria. She is a Senior Lecturer and under consideration for Readership in English Linguistics. She hopes to engage in further research in the documentation of the Nigerian indigenous languages, which is one of the current research interests that she is pursuing. She is a member of Nigeria English Studies Association. 